\title{
CHARMED, I'M SURE
}

What makes the perfect protein purification or the right reagent reaction?

Trevor Stokes investigates the weird world of good-luck lab charms.

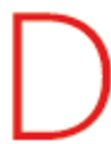

aniel Nelson was getting desperate. His graduate thesis at the University of Georgia, Athens, depended on his ability to isolate periodontain, an enzyme from the bacterium that causes gum disease. Yet after two years of trial and error, his protein preparation still contained too many contaminants.

Enter the lucky sombrero. For his 26th birthday, Nelson's lab mates took him to a Mexican restaurant. The birthday boy asked the waiter if he could wear a sombrero hanging on the wall - then, after sharing several pitchers of margaritas, Nelson wore the hat back to the lab. Luck finally struck: the new protein-isolation protocol he had started earlier that morning showed that he had finally isolated his favourite protein.

The 'purification sombrero' quickly gained a following among postdocs and students in the lab. "They have all heard the story and know if they don't wear the hat, they will be cursed with two years of impure protein," says Nelson, who is now an assistant professor at Rockefeller University in New York.

Similar good-luck charms populate laboratories worldwide. As childish as they may seem, such totems can benefit researchers on several levels as a bonding activity to bring lab members together; a giver of hope when experiments are failing or a silly release to take the edge off serious research pursuits. Stuart Vyse, a psychologist at Connecticut College, New London, says superstitions can help lab members bond in a sort of "psychological hopefulness".

\section{Magical mascots}

Charms can be found in nearly every aspect of science, from biochemistry labs that depend on reagents working properly to observatories that require clear skies.

To that end, dozens of fist-sized cloth ghosts line the ceiling of the control room at the

s. Subaru Observatory at the summit of

Mauna Kea, Hawaii. In Japan, elemen-

tary-school children typically use such charms, called teru-teru bozu - 'sunshine monks' in English - to ensure good weather for class trips and holidays. What's good for trips is good for telescopes, say staff astronomers. "Over a period of time, each astronomer who subscribes to that superstition will add one or more of these things," says Gary Fujihara, an educator at the University of Hawaii's Institute for Astronomy at Manoa.

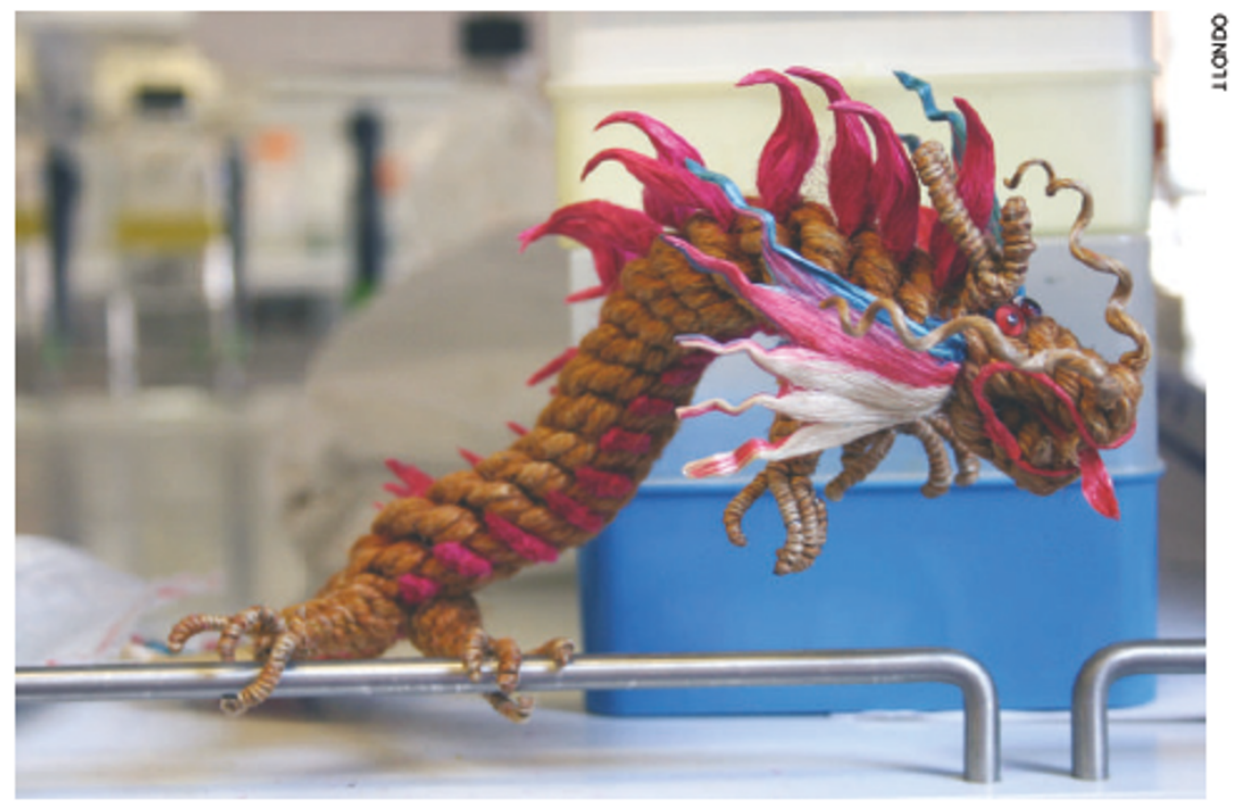

Toy story: an unnamed twine dragon, above, and Squeaky the dinosaur, below, assist successful PCR.

Scientists and technicians tend to pass down their charm traditions. John Gaskin, a former postdoc at Washington University in St Louis, Missouri, introduced graduate student Jason Londo to the 'amulet of power' - a fakejewel-encrusted gold chain that students wore while conducting polymerase chain reactions (PCRs). "If it works, cool," says Londo. "And if somebody has a problem with that, we'll just see where they go when their PCR stops working." The amulet disappeared last year, but Londo replaced it with a dragon made out of twine and ribbons.

Some scientists call on their colleagues for ideas for charms, which suggests that the line between fiction and fact can be crossed in the name of social fun. On Protocol Online, a lifesciences protocol database, a recent forum read "The Gods of Molecular Biology. - Pay homage! Share your experience! $!^{m}$ Three authors fretted about choosing the right sacrifice for experiments to work.

"My sacrifice of a KitKat and
Diet Coke every morning results in having PCR reactions work (which, without the sacrifice, don't work at all), claimed author vetticus 3 . Hobglobin responded: "Our PCR spirits are very busy. They appear to us as squirrels and in our PCR room several squirrel statues and posters are placed to honour them.

\section{Superstitious minds}

Failure can also bring out the lab charms. At the University of Utah, Salt Lake City, an assistant professor of human genetics arranges voodoo candles in her lab to pay homage to the gods of cloning. "It's a little bit of a humorous comfort to people," she says, "to see that other people can make a joke out of failure." But her embarrassment over the practice - she asked not to be named, for fear of not getting tenure - suggests the charm of good-luck trinkets fizzles out as scientists become more established. Graduate students and postdoctoral fellows are more often the ones setting up good-luck charms, compared with older laboratory heads.

But Rich Whitkus, a plant evolutionary biologist at Sonoma State University in California, has kept Squeaky, a high-pitched dinosaur, for more than a decade after graduate school. "It's one of the first things that gets set up in the lab," says Whitkus. He has witnessed other researchers squeeze the dinosaur before starting PCR reactions. "Of course, we have no correlation that the number of squeaks that Squeaky gets is directly correlated with the success of PCR," he says. "We have no scientific data on that." Trevor Stokes is a freelance writer in New York City. 